Brit. J. Ophthal., (1952), 36, 438.

\title{
SURVIVAL OF RETINAL ELEMENTS IN SUBCUTANEOUS HOMOGRAFTS*
}

\author{
BY \\ GEORGE M. WYBURN AND PAUL BACSICH \\ From the Anatomy Department, University of Glasgow
}

THE numerous publications of Stone (1930-50) on the results of transplantation of the eyes of urodeles must form the essential background for any work in this field. According to these experiments, transplantation of the adult eye results in a preliminary degeneration of the retina, followed by histological regeneration with ultimate functional recovery. Koppányi (1923a, b, c, d) claimed similar results from transplanting the eyes of rats, and subsequent histological examination of his material by Kolmer (1923) appeared to confirm that there was some evidence of the presence of the normal retinal tissue. There is, however, a disinclination to accept the claims of Koppányi without a good deal more evidence from further experiments of a similar nature.

It is generally considered that the mammalian retina would succumb quickly and completely to any interference with its blood supply. Grafting of mammalian retinal tissue involving a prolonged period of avascularity would generally be predicted an inevitable failure. It thus seems worth while to record some unexpected evidence of the persistence and survival of grafted mammalian retinal tissue found in the course of experiments with corneal homografts in the guinea-pig.

\section{Material and Methods}

As previously described (Bacsich and Wyburn, 1947), homografts of the anterior part of the guinea-pig eye were implanted into the subcutaneous tissue of another guinea-pig. These grafts were originally intended for the study of the survival capacity of corneal tissue, but were subsequently found to include portions of the sclera, the ciliary bodies, and peripheral parts of the retina (in the region of the ora serrata). The grafts were removed at periods between 3 and 4 weeks, sectioned, and stained for histological study.

\section{Findings}

Retinal elements were found in four of the homografts. Fig. 1 shows the retinal elements found in graft 1A. The appearance resembles the peripheral region of the normal guinea-pig retina. There is an interrupted row of ganglion cells indicated by the characteristic large nuclei with well-marked nucleoli. Adjacent to this is a layer of bipolars with rows of nuclei in part obscured by pigment granules. This layer of bipolars thins out towards the ora serrata. There are no rods and cones, although the rods at any rate are normally found in the peripheral regions of the retina. This was a fairly typical section.

In other grafts (e.g., Fig. 2) the rod and cone elements are replaced by a single row of low columnar cells which may be derived from the non-pigmented epithelial cells of the pars ciliaris retinae or may be a metamorphosis or de-differentiation

* Received for publication March 29, 1952. 


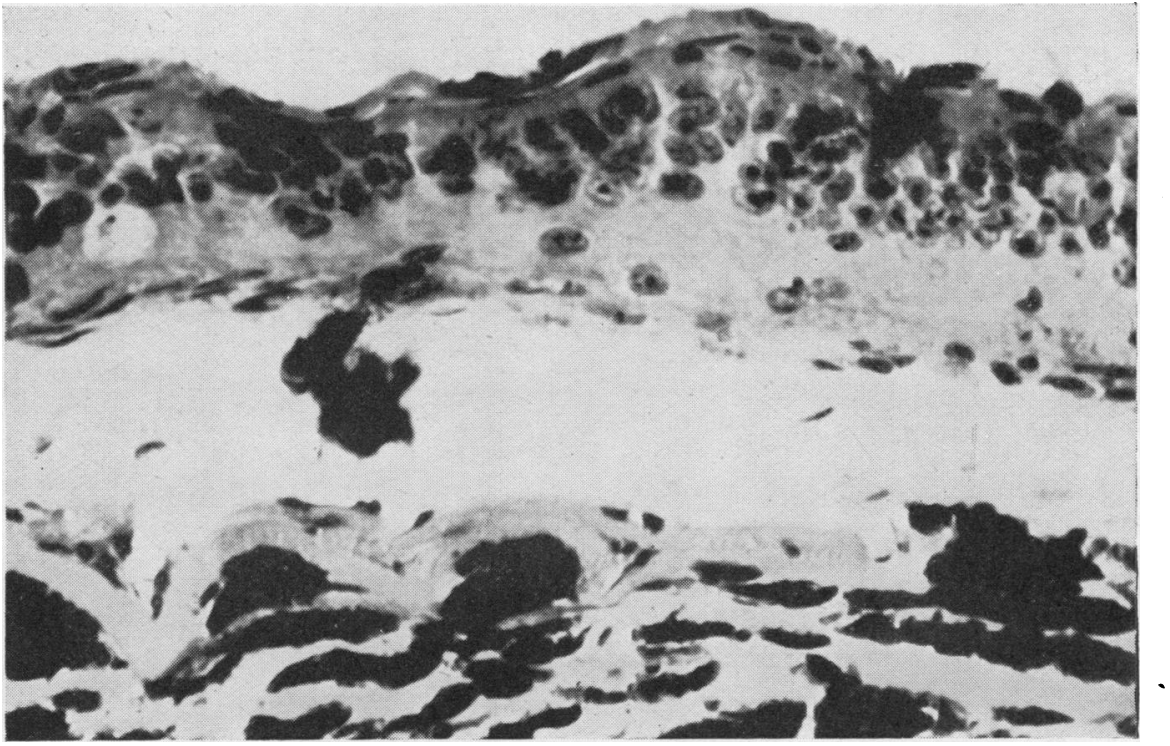

Fig. 1.-Retina from region of ora serrata. $\quad \times 640$.

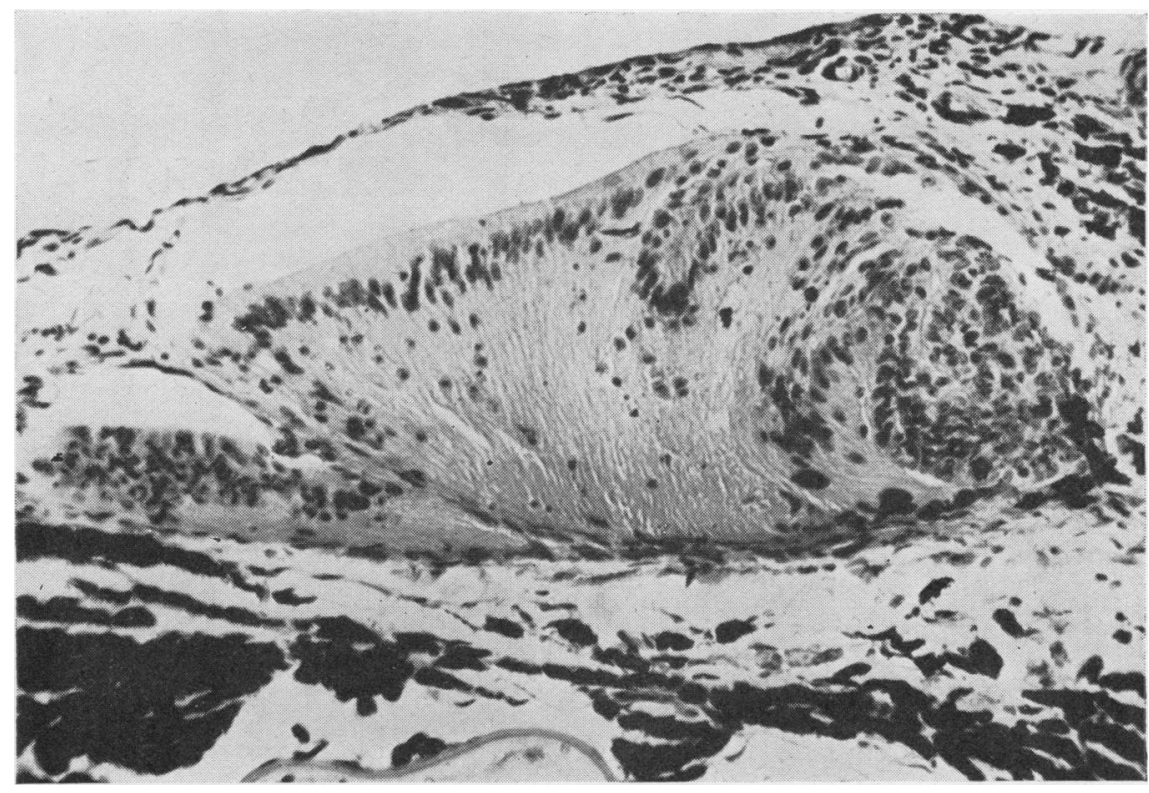

FIG. 2.-Retina adjoining region of ora serrata. $\times 245$.

of the neuro-epithelial sensory cells. These columnar cells cap a zone of bipolars several layers thick (left of Fig. 2). The remainder of the retina in this section has been cut tangentially, hence the broad appearance. Here, there are fewer ganglion and bipolar cells and the surface columnar cells appear to be pseudo-stratified. 
The right-hand portion of the retina consists of a spherical mass of tissue made up of optic fibres, ganglion cells, inner plexiform layer, and bipolar cells, together with columnar epithelium. This part of the retina is invaded by cells from the pigment layer, showing active cellular proliferation not unlike tumour formation.

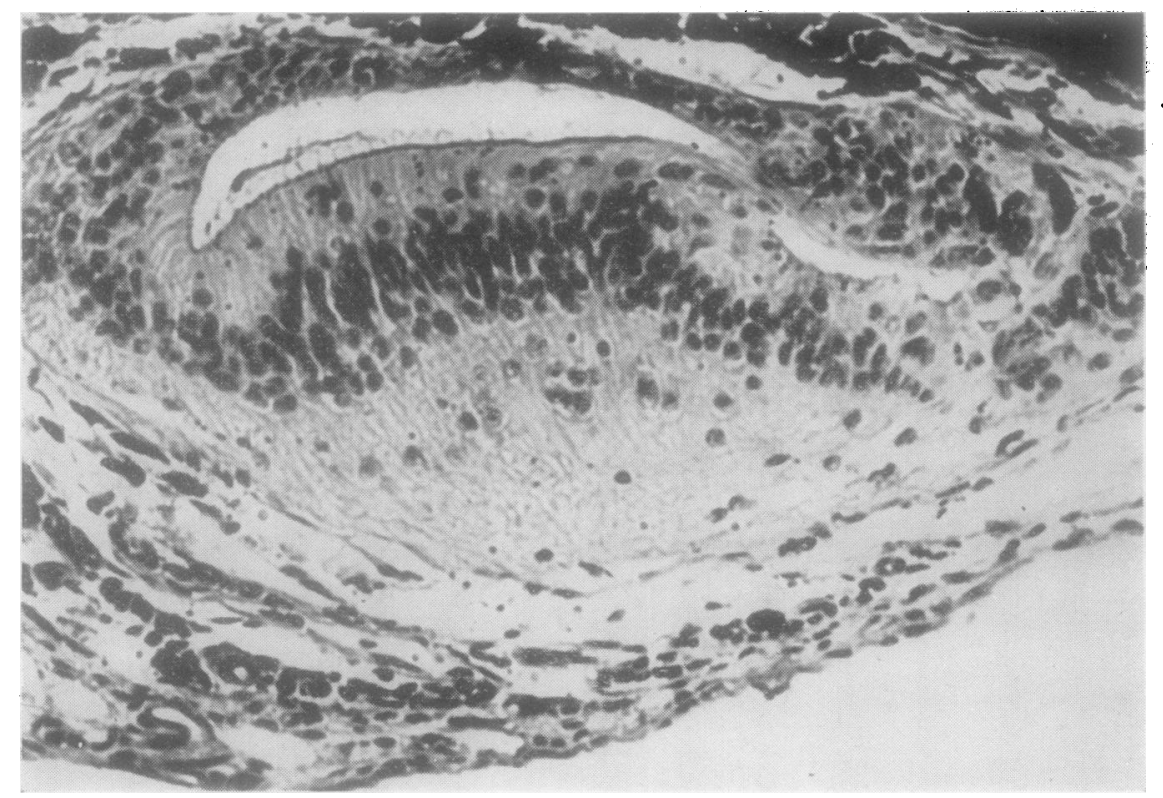

FIG. 3.--Retina from equator of eye. Observe cyst formation imitating a developing lens vesicle. $\times 340$.

As in other subcutaneous grafts, particularly of skin, there is a tendency to cyst formation (Fig. 3) in which it may be difficult to recognize specific retinal elements. Fig. 3 represents such a retinal cyst, superficially reminiscent of a developing lens vesicle. In the lower part of the cyst are optic nerve fibres, ganglion cells, the inner plexiform layer, and the layer of bipolar cells. There is a narrow outer plexiform layer and, adjacent to this, a few rod and cone cell nuclei. The remainder of the receptor elements, however, cannot be recognized and appear to be replaced by a number of basophilic, rounded bodies resting on the outer limiting membrane and occasionally invading the superficial layers of the retina. The wall of the cyst rapidly thins towards the equator and obscures the orientation of the retinal layers. The thinned-out roof of the cyst is invaded by the cells of the pigmented epithelium of the retina with a characteristic zone of vigorous cellular proliferation on the right-hand side.

These areas of proliferating cells are not only present in the midst of retind elements, but also occur as characteristic isolated entities, which we were tempted to term " retinomata" (Figs 4 and 5). They include optic fibres, ganglion cells, and what probably corresponds to the inner plexiform layer. In the centres of these retinomata, are dense clusters of cells in the position of the bipolar cells, showing active proliferation. The origin and fate of these retinomata have still to 


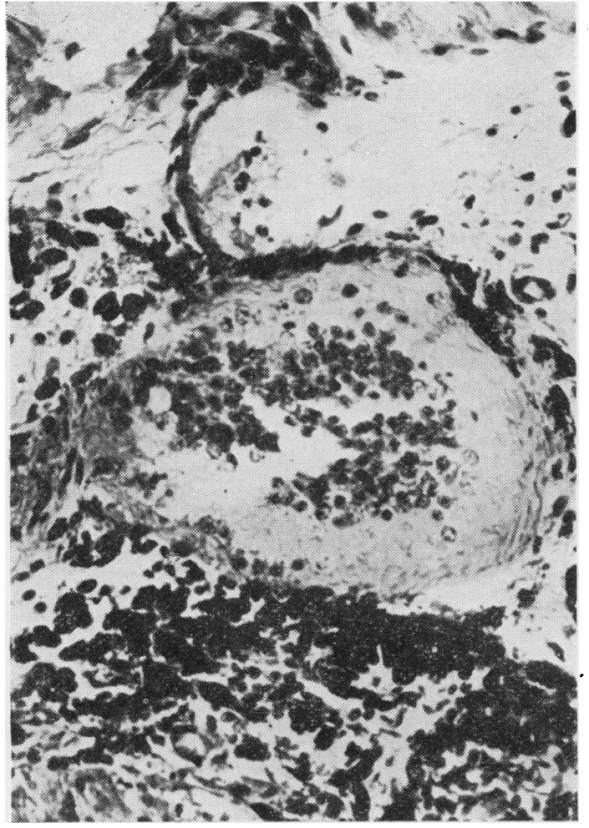

FIG. 4.-Large " retinoma ". $\times 280$.

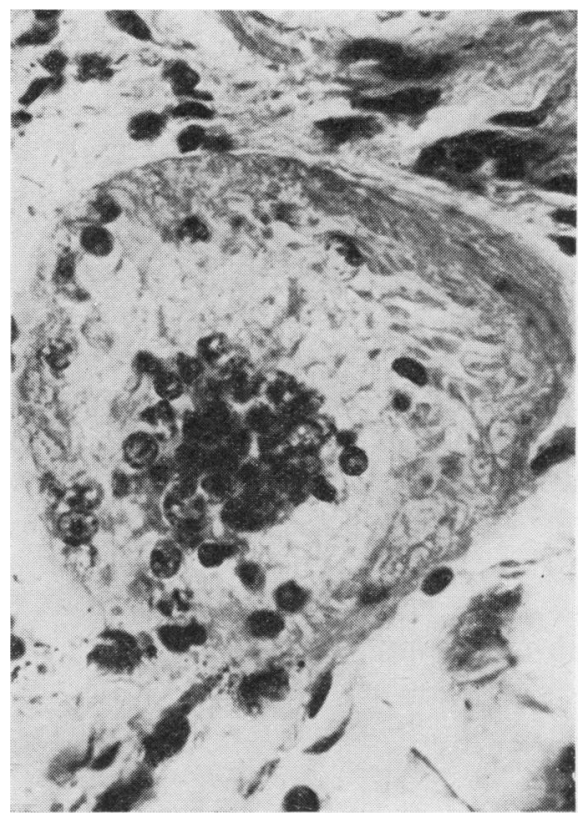

FIG. 5.-Smaller " retinoma ". $\times 520$.

be ascertained; they may represent active proliferation of surviving retinal elements but may, on the other hand, have a neuroglial origin or be derived from the epithelial elements of the pars ciliaris retinae.

Fig. 6 shows an interesting section. In the centre is a double layer of non-

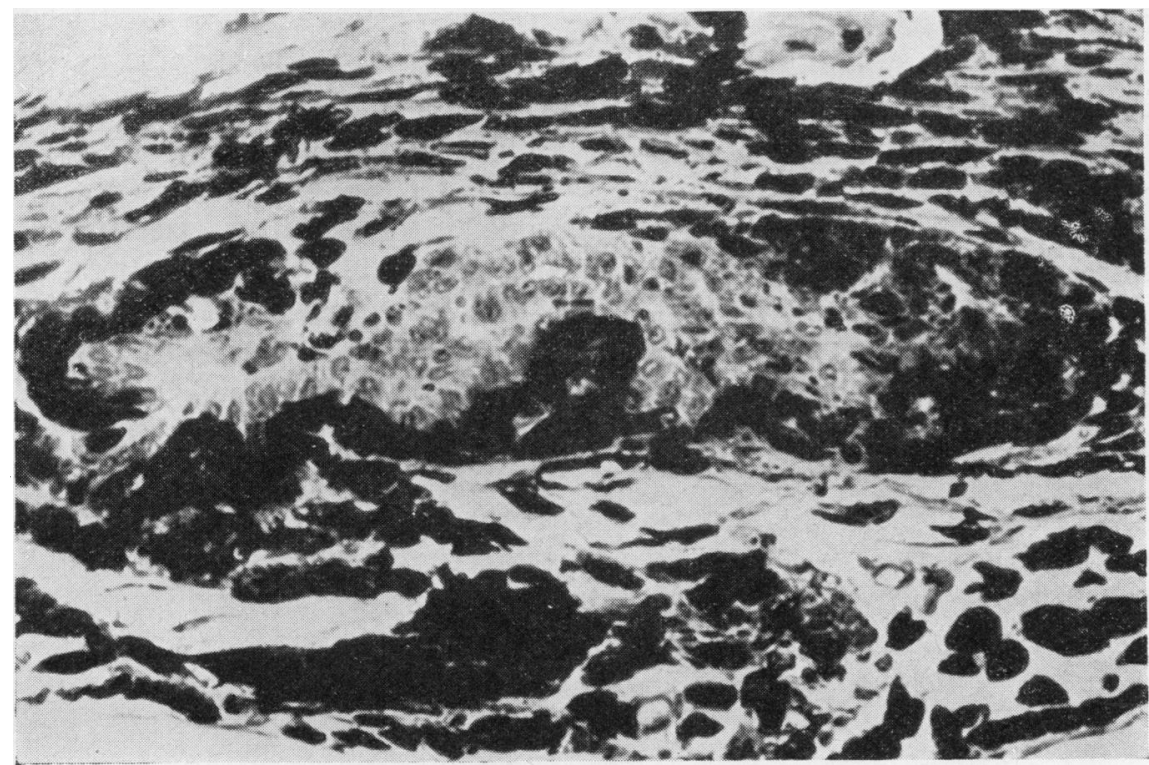

Fig. 6.-Extensive proliferation of retinal pigment cells with a central cluster of non-pigmented epithelial cells. $\times 340$. 
pigmented epithelial cells (an attempt at regeneration?) surrounded by a peripheral zone of heavily pigmented cells. The whole appearance is not unlike some of Stone's illustrations of the early stages of regeneration of the retina from the pigmented epithelium.

\section{Discussion}

That mammalian retinal tissue can survive when deprived of its blood supply for a number of hours, if not days, is a finding of significance. The time factor, together with the histological picture, indicates that the question here is one of survival and not of regeneration of the retina. Stone records survival of retinal tissue in the transplanted eyes of larval anurans, but in the adult specimens the temporary loss of blood supply which occurred during the operation caused degeneration of all the retinal elements of the transplanted eyes. This is evident within 6 days and complete after 16 days.

The loss of vision which follows embolus of the central artery of the retina in man is presumably due in the first place to functional failure in the fibres of the optic nerve. We have been unable to find any account of the immediate histological effects on the human retina of interference with the central vessels. There is, however, a considerable literature on the results of blocking or cutting the central artery in animals (Wagenmann, 1890; Hertel, 1898; Birch-Hirschfeld, 1900; Schreiber, 1906; Guist, 1926). In these experiments, necrosis of the ischaemic regions of the retina occurs, and affects particularly the second and third neurons, as would be expected from the distribution of the central artery. Suppression of the circulation for longer than 15 minutes produces permanent changes in the rat retina, and there is complete degeneration of the ganglion cells after half an hour. At present we are content to record without any attempted explanation that neural elements of the guinea-pig retina can persist and survive as histological entities after transplantation. Whether they would still be able to function as visual receptors if they were restored to normal conditions remains hypothetical.

In most recorded transplantation experiments, the eyes were first enucleated, then replaced in the orbit of the same animal. They were thus autotransplants, and their ultimate fate-survival and regeneration-solely a nutritional concern. Here we are dealing with homotransplants, where the tissues have to reckon with a host reaction. The major portion of the graft consists of the cornea showing perfect histological preservation, as was expected. We have suggested elsewhere (Wyburn and Bacsich, 1947) that the well-known survival capacity of cornea and cartilage when homotransplanted is due to the measure of protection afforded to tissues rich in mucoproteins. Mucoproteins, by virtue of their polysaccharide component, are non-antigenic and would thus not promote an antigen-antibody reaction; or, in terms of the genetic cellular hypothesis, the mucoproteins would neutralize the individuality differential. In the present homografts, largely 
consisting of corneal tissue, there was little or no host reaction, and it seems probable that the retinal tissue was enjoying a protection afforded by the abundant mucoproteins of the cornea. However, the whole question of the varying survival capacity of homotransplanted tissues has still to be satisfactorily explained. In man, homografts of skin may survive for 7 or 8 weeks, although they generally slough off in 3 to 4 weeks. Homograft bone commences to degenerate very rapidly, but, because of the nature of the tissue, the degeneration may not be completed for several weeks. It is obviously not possible, on the basis of these experiments, to advance any views on the survival capacity of retinal tissue. Further experiments require to be made on a much larger scale, over a longer period, and with retinal grafts, with and without corneal tissue.

The occurrence of clusters of exuberantly proliferating pigmented epithelial cells was of special interest (Fig. 6). In the transplanted urodele eye these cells reform the retina (Stone, 1950), and they appear to possess a vigorous and aggressive vitality surpassing that of neighbouring tissues.

\section{Summary}

A report is made of an incidental finding of surviving retinal tissue during experiments with homografts of cornea.

\section{REFERENCES}

Bacsich, P., and Wyburn, G. M. (1947). Proc. roy. Soc. Edin. B., 62, Part III, 321. BIRCH-HIRSCHFELD, A. (1900). v. Graefes Arch. Ophthal., 50, 166.

GuIST, G. (1926). " Klinische Betrachtungen und experimentelle Ergebnisse zur Frage über die Erholungsfähigkeit der Netzhaut nach unterbrechung der Blutzirkulation ". Abhandlungen aus der Augenheilkunde und ihren Grenzgebieten. Heft 1. (Beiheft zur Ztschr. f. Augenheilk.)

Hertel, E. (1898). v. Graefes Arch. Ophthal., 46, 277.

Kolmer, W. (1923). Arch. mikr. Anat., 99, 64.

KOPPÁNYI, T. (1923a). Ibid., 99, 15.

- (1923b). Ibid., 99, 42.

- (1923c). Ibid., 99, 60.

(1923d). Ibid., 99, 76.

SCHREIBER, L. (1906). v. Graefes Arch. Ophthal., 64, 237.

STONE, L. S. (1950). Anat. Rec., 106, 89 (see this article for earlier publications).

Wagenmann, A. (1890). v. Graefes Arch. Ophthal., 36, Abt. 4, 1. 